\title{
Analisis Perbedaan Nilai Paparan Medan Listrik pada Biji Buncis (Phaseolus vulgaris $l$.) Terhadap Panjang Tanaman yang Dihasilkan
}

\section{(Analysis of Differences Electric Field Exposure Value in Bean (Phaseolus vulgaris L.) Seeds on The Length of The Produced Plant)}

\author{
Asviyatu Nisa, ${ }^{\text {*) }}$, Muhammad Helmi Hakim ${ }^{1)}$, dan Yuanita Amalia Hariyanto ${ }^{1)}$ \\ ${ }^{1)}$ Program Studi Fisika, Fakultas Ilmu Eksakta, Universitas Nahdlatul Ulama Blitar \\ *) Email korespondensi: n.asviyatu@gmail.com
}

\begin{abstract}
The effect of an electric field on plant roots can affect plant growth and development, plants growing in an electric field cause cell and tissue polarization and can affect plant root growth. This study aims to determine the effect of the electric field on the length of the bean plant. In this study, the electric field application used for field treatment was $0.5 \mathrm{kV} / \mathrm{m}, 1 \mathrm{kV} / \mathrm{m}, 1.5 \mathrm{kV} / \mathrm{m}$, and $2 \mathrm{kV} / \mathrm{m}$ for 60 minutes. The results obtained from this study indicate that the electric field can accelerate the growth of bean plant length. The most suitable electric field to accelerate germination growth is an electric field of $1 \mathrm{kV} / \mathrm{m}$.
\end{abstract}

Keywords: Electric field, green beans, plant length.

\begin{abstract}
ABSTRAK
Efek medan listrik terhadap akar tanaman dapat mempengaruhi pertumbuhan dan perkembangan tanaman, tanaman yang tumbuh di antara medan listrik menyebabkan polarisasi sel dan jaringan serta dapat mempengaruhi pertumbuhan akar tanaman. Penelitian ini bertujuan untuk mengetahui efek medan listrik terhadap panjang tanaman buncis. Dalam penelitian ini aplikasi medan listrik yang digunakan untuk perlakuan medan sebesar $0,5 \mathrm{kV} / \mathrm{m}, 1 \mathrm{kV} / \mathrm{m}, 1,5 \mathrm{kV} / \mathrm{m}$, dan $2 \mathrm{kV} / \mathrm{m}$ selama 60 menit. Hasil yang diperoleh dari penelitian ini menunjukkan bahwa medan listrik dapat mempercepat pertumbuhan panjang tanaman buncis. Medan listrik yang paling sesuai untuk mempercepat pertumbuhan perkecambahan adalah medan listrik sebesar $1 \mathrm{kV} / \mathrm{m}$.
\end{abstract}

Kata Kunci: Medan listrik, biji buncis, panjang tanaman.

\section{PENDAHULUAN}

Radiasi merupakan suatu emisi (pancaran) dan perambatan energi melalui ruang atau materi dalam bentuk partikel maupun (Amel et al., 2019). Radiasi elektromagnetik merupakan salah satu faktor lingkungan fisik yang perlu diperhatikan. Hal ini dikarenakan pancaran radiasi elektromagnetik dapat menimbulkan dampak berupa gangguan fisiologis maupun psikologis. Radiasi elektromagnetik merupakan gabungan antara medan magnet dan medan listrik yang berosilasi serta merambat melewati ruang kemudian membawa energi dari satu tempat ke tempat yang lain (Syaifuddin, 2011).
Medan listrik merupakan medan yang dihasilkan oleh muatan listrik atau medan magnet yang bergerak. Medan tersebut terdapat disekitar muatan listrik, dimana muatan lain yang berada didekatnya akan merasakan gaya tarik atau gaya tolak.

Seiring dengan berkembangnya penelitian tentang pengaruh medan listrik terhadap manusia dan hewan mendorong beberapa peneliti untuk menyelidiki adakah pengaruh medan listrik terhadap pertumbuhan tanaman. Tanaman yang tumbuh di antara medan listrik menyebabkan polarisasi sel dan jaringan serta dapat mempengaruhi pertumbuhan akar tanam. Hasil dari penelitian 
Kiatgamjorn dkk, (2002); dalam Agustin (2013) , menunjukkan bahwa kacang yang tumbuh di medan listrik memiliki pertumbuhan lebih baik, dibandingkan tanpa medan listrik.

Germinasi (perkecambahan) merupakan proses pertumbuhan embrio dan komponenkomponen biji yang memiliki kemampuan untuk tumbuh secara normal menjadi tumbuhan baru. Didalam proses perkecambahan, radikula (akar embrionik) mengalami perpanjangan kearah luar menembus kulit biji. Di balik gejala morfologi dengan pemunculan radikula tersebut, terjadi proses fisiologi-biokemis yang kompleks, dikenal sebagai proses perkecambahan fisiologis (Agustin, 2013).

Buncis (Phaseolus vulgaris L.) merupakan tumbuhan holtikultura yang termasuk dalam jenis tanaman kacangkacangan dan berpotensi dikembangkan karena berperan dalam memenuhi kebutuhan konsumsi nasional serta sebagai komoditas ekspor (Sirait \& Sugito, 2020). Menurut Badan Pusat Statistik tahun 2018, produksi tanaman buncis nasional pada tahun 2014-2018 mengalami penurunan berturut-turut, hal ini berbanding terbalik dengan kebutuhan masyarakat yang semakin meningkat seiring dengan bertambahnya jumlah penduduk setiap tahunnya.

Belum terpenuhinya kebutuhan dalam negeri dan ekspor diakibatkan oleh Produksi tanaman buncis yang berfluktuasi dan cenderung masih rendah. Salah satu faktor yang menyebabkan rendahnya produksi buncis di Indonesia yaitu produksi buncis yang belum dapat berjalan secara kontinuitas serta kualitas dan kuantitas yang belum memenuhi pasar (Srirejeki et al., 2015). Dengan adanya kendala tersebut, maka dibutuhkan solusi untuk meningkatkan produktivitas dan kualitas tanaman buncis, salah satu hal yang dapat dilakukan adalah dengan memberikan paparan medan listrik.

Berdasarkan penjelasan tersebut, maka diperlukan penelitian lebih lanjut dalam mendukung penelitian sebelumnya mengenai efek paparan medan listrik pada biji buncis terhadap panjang tanaman yang dihasilkan dengan menggunakan elektroda yang terbuat dari tembaga. Penelitian ini bertujuan untuk mengetahui besar medan listrik terbaik serta lama waktu paparan optimum terhadap panjang tanaman buncis.

\section{METODOLOGI PENELITIAN}

\section{Alat dan Bahan}

Alat yang digunakan dalam penelitian ini yaitu alat medan listrik, multimeter, tray semai, tanah, pupuk kompos, penggaris, benang. Sedangkan bahan yang digunakan yaitu biji tanaman buncis.

\section{Pelaksanaan Penelitian}

Penelitian ini dimulai dengan studi literatur, yaitu tahap awal untuk mengumpulkan referensi yang menunjang penelitian. Selanjutnya dilakukan persiapan alat dan bahan untuk dilakukan pengadaan pemenuhan kebutuhan alat dan bahan yang digunakan. Dalam penelitian ini, alat yang digunakan yaitu berupa dua lempeng logam berdiameter $15 \mathrm{~cm}$ dan dipisahkan dengan jarak $2 \mathrm{~cm}$ yang dihubungkan dengan sumber tegangan yaitu listrik. Sumber tegangan sebesar 5 VDC digunakan untuk menghasilkan beda potensial antara dua lempeng. Beda potensial akan timbul diantara kedua lempeng saat rangkaian listrik ditutup kemudian menghasilkan medan listrik homogen sebesar $\frac{\Delta V}{d}$. Dengan $\Delta V$ beda potensial antar pelat dan d adalah jarak antar pelat. Pada tahap perlakuan dilakukan pengulangan sebanyak 3 kali untuk setiap variasi medan listriknya. Dalam penelitian ini masing-masing biji dipapari selama 60 menit dan diletakkan diantara kedua pelat logam dengan tegangan yang digunakan yaitu sebesar $10 \mathrm{~V}, 20 \mathrm{~V}, 30 \mathrm{~V}$, dan $40 \mathrm{~V}$ untuk menghasilkan kuat medan listrik sebesar $0,5 \mathrm{kV} / \mathrm{m}, 1 \mathrm{kV} / \mathrm{m}, 1,5 \mathrm{kV} / \mathrm{m}$, dan $2 \mathrm{kV} / \mathrm{m}$ sesuai dengan persamaan (Ardiansyah \& Pramudita, 2020):

$$
\mathrm{E}=\frac{V}{d}
$$

keterangan:

$\mathrm{E}=$ magnitude dari kuat medan listrik $(\mathrm{V} / \mathrm{m})$

$\mathrm{V}=$ tegangan pada elektroda plat (Volt)

$\mathrm{d}=$ jarak antara dua plat $(\mathrm{m})$ 


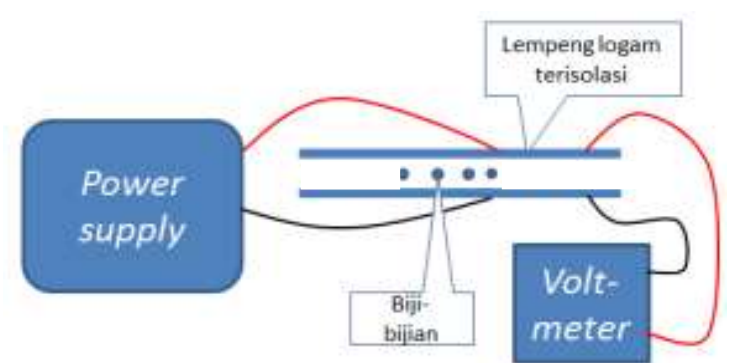

Gambar 1. Alat Sumber Medan Listrik (Romadhon \& Khotimah, 2015)

\section{Pengamatan dan Analisis Data}

Pengukuran panjang tanaman buncis dilakukan dengan mengukur panjang tanaman dari ujung akar hingga ujung pucuk daun. Pengukuran dilakukan dengan bantuan benang yang kemudian benang diukur dengan bantuan penggaris. Dalam penelitian ini, metode yang digunakan yaitu metode statistik deskriptif. Penggunaan metode ini bertujuan untuk meggambarkan variabel-variabel dalam penelitian. Analisis yang digunakan untuk mendeskripsikan variabel tersebut yaitu ratarata (mean), minimum dan maksimum, serta standar deviasi.

\section{HASIL DAN PEMBAHASAN}

\section{Hasil dan Analisis}

Hasil pengukuran pada seluruh perlakuan medan listrik dan kontrol serta nilai rata-rata setiap veriabel disajikan pada Tabel 1 dan 2 . Dari hasil pengukuran, terlihat bahwa setiap tanaman memiliki pertumbuhan yang berbeda untuk setiap perlakuan medan listrik dan kontrol.

Tabel 1. Hasil pengukuran panjang tanaman buncis

\begin{tabular}{|c|c|c|}
\hline $\begin{array}{c}\text { Kuat Medan } \\
\text { Listrik (kV/m) }\end{array}$ & $\begin{array}{c}\text { Panjang } \\
\text { Tanaman }(\mathbf{c m})\end{array}$ & $\begin{array}{c}\text { Ulangan } \\
\text { ke- }\end{array}$ \\
\hline Kontrol & 0 & 1 \\
\hline Kontrol & 0 & 2 \\
\hline Kontrol & 7.8 & 3 \\
\hline 0.5 & 18 & 1 \\
\hline 0.5 & 17.2 & 2 \\
\hline 0.5 & 12.5 & 3 \\
\hline 1 & 16.2 & 1 \\
\hline 1 & 21.7 & 2 \\
\hline 1 & 20.6 & 3 \\
\hline 1.5 & 17.5 & 1 \\
\hline 1.5 & 18.6 & 2 \\
\hline 1.5 & 7.3 & 3 \\
\hline 2 & 0 & 1 \\
\hline
\end{tabular}

\begin{tabular}{|c|c|c|}
\hline $\begin{array}{c}\text { Kuat Medan } \\
\text { Listrik (kV/m) }\end{array}$ & $\begin{array}{c}\text { Panjang } \\
\text { Tanaman }(\mathbf{c m})\end{array}$ & $\begin{array}{c}\text { Ulangan } \\
\text { ke- }\end{array}$ \\
\hline 2 & 19.6 & 2 \\
\hline 2 & 16.3 & 3 \\
\hline
\end{tabular}

Tabel 2. Hasil perhitungan rata-rata Panjang tanaman pada setiap pengulangan

\begin{tabular}{|c|c|c|}
\hline $\begin{array}{c}\text { Kuat Medan } \\
\text { Listrik (kV/m) }\end{array}$ & $\begin{array}{c}\text { Lama } \\
\text { Paparan } \\
\text { (menit) }\end{array}$ & $\begin{array}{c}\text { Panjang } \\
\text { Tanaman } \\
\text { (cm) }\end{array}$ \\
\hline Kontrol & 60 & 2.6 \\
\hline 0.5 & 60 & 15.9 \\
\hline 1 & 60 & 19.5 \\
\hline 1.5 & 60 & 14.5 \\
\hline 2 & 60 & 12 \\
\hline
\end{tabular}

Berdasarkan hasil pengukuran pada kelompok kontrol dan eksperimen, didapatkan pula hasil analisis deksriptif kuantitatif untuk pemberian medan listrik terhadap pertumbuhan panjang tanaman buncis, dapat dilihat pada tabel berikut:

Tabel 3. Analisis deskriptif hasil pengukuran panjang tanaman buncis

\begin{tabular}{|c|c|}
\hline Statistik & Skor Statistik \\
\hline Jumlah sampel & 5 \\
\hline Nilai minimum & 2.6 \\
\hline Nilai maksimum & 19.5 \\
\hline Rata-rata & 12.9 \\
\hline Standar deviasi & 6.36 \\
\hline
\end{tabular}

Dari Tabel 3, untuk hasil pengukuran panjang tanaman diketahui bahwa nilai minimum sebesar 2.6, nilai maksimum sebesar 19.5, nilai rata-rata adalah sebesar 12.9 , serta standar deviasi sebesar 6.36 artinya nilai ratarata lebih besar dari nilai standar sehingga penyimpangan data yang terjadi rendah maka penyebaran nilainya merata.

Berikut ini merupakan hasil analisis dalam bentuk diagram untuk hasil pengukuran panjang tanaman dari percobaan eksperimen maupun kontrol. 


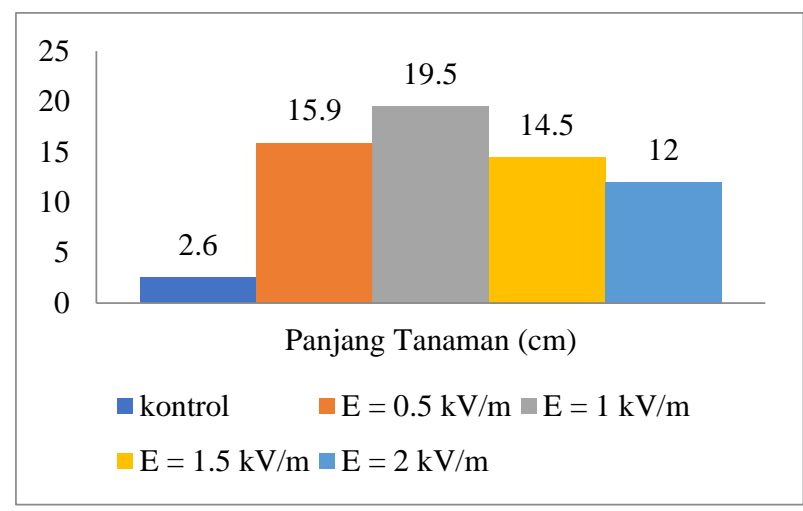

Gambar 2. Diagram panjang tanaman buncis

Berdasarkan gambar diatas, efek paparan medan listrik terhadap panjang tanaman dengan waktu paparan 60 menit yakni pada kelompok eksperimen mendapatkan hasil lebih tinggi dibandingkan dengan kelompok kontrol. Untuk hasil dari diagram pengukuran tersebut merupakan rata-rata dari setiap sampel kelompok eksperimen maupun kelompok kontrol.

\section{Pembahasan}

Paparan medan listrik pada gambar 2 diatas terhadap proses pertumbuhan tanaman buncis mengalami kenaikan pada kelompok eksperimen. Kelompok eksperimen dengan kuat medan listrik $0.5 \mathrm{kV} / \mathrm{m}$ sampai $2 \mathrm{kV} / \mathrm{m}$ mendapatkan hasil rata-rata yang lebih tinggi dibandingkan dengan kelompok kontrol. Pemberian medan listrik pada tanaman buncis dimaksudkan untuk mengamati proses pertumbuhan tanaman buncis dengan indikator pengukurannya yaitu panjang tanaman yang dihasilkan.

Penelitian sebelumnya membuktikan bahwa pertumbuhan tanaman kacang lebih baik apabila berada diantara medan listrik. Tanaman yang tumbuh dan berada diantara medan listrik akan menyebabkan polarisasi pada sel dan jaringan tanaman (Kiatgamjorn dkk., 2002). Penelitian lain mengatakan bahwa apabila aliran medan listriknya rendah, dapat mengganggu pola pembelahan sel namun apabila medan listriknya terlalu tinggi maka dapat pula merusak akar (Waawrecki, 2007).

Pemberian perlakuan dengan medan listrik terbukti telah mempercepat laju pertumbuhan. Hasil rata-rata yang diperoleh dari pengukuran panjang tanaman dari keempat perlakuan menggunakan medan listrik yang paling cocok untuk pertumbuhan tanaman buncis yaitu pada medan listrik sebesar $1 \mathrm{kV} / \mathrm{m}$ karena memiliki masa pertumbuhan paling cepat jika dibandingkan dengan perlakuan lainnya. Hal ini menunjukkan bahwa ruang dalam media pertumbuhan pada daerah medan listrik sebesar $1 \mathrm{kV} / \mathrm{m}$ merupakan kondisi klimatik yang sesuai sehingga benih buncis dapat memulai proses perkecambahan dengan cepat. Paparan dengan lama waktu 60 menit memberikan efek baik pada proses pertumbuhan tanaman buncis. Waktu tersebut menunjukkan pertumbuhan maksimal pada tanaman terhadap perlakuan medan listrik. Dimungkinkan bahwa biji yang dipapari medan listrik dengan waktu tersebut dapat mempercepat proses perkecambahan.

Berdasarkan pembahasan diatas, pada kuat medan listrik $1 \mathrm{kV} / \mathrm{m}$ dengan lama paparan 60 menit merupakan waktu optimum medan listrik untuk pemaparan pada biji buncis, sehingga memberikan dampak positif dan mempercepat laju pertumbuhan tanaman buncis. Dapat disimpulkan bahwa pada kuat medan listrik dan lama waktu tersebut tanaman lebih cepat tumbuh dibandingkan dengan perlakuan yang lain.

\section{KESIMPULAN}

Berdasarkan penelitian yang telah dilakukan, maka dapat disimpulkan bahwa besar kuat medan listrik optimum yang dibutuhkan untuk mempercepat pertumbuhan panjang tanaman buncis yaitu sebesar $1 \mathrm{kV} / \mathrm{m}$ dengan lama waktu paparan 60 menit.

\section{DAFTAR PUSTAKA}

Agustin CD, R. (2013). Efek Medan Listrik DC Terhadap Dormansi dan Germinasi Benih Semangka (Citrullus lanatus).

Ardiansyah, N. P., \& Pramudita, R. (2020). Karakteristik Surface Partial Discharge Di Sekitar Antarmuka Pcb Pada PelatPelat Elekroda Pada Isolasi Udara Dan Minyak. Jurnal Ilmiah Teknologi Infomasi Terapan, 6(2), 65-73. https://doi.org/10.33197/jitter.vol6.iss 2.2020.373. 
Romadhon, D. R., \& Khotimah, S. N. (2015). Pengaruh Besar Medan Listrik Statis Homogen dan Lama Waktu Paparan Terhadap Perkecambahan Biji Vigna Radiata, dan Oryza Sativa. Prosiding Simposium Nasional Inovasi Dan Pembelajaran Sains, 8-9.

S, A. O., Milvita, D., \& Darlina, D. (2019). Studi Awal Pengaruh Radiasi Terhadap Pekerja Radiasi Menggunakan Metode Comet Assay. Jurnal Ilmu Fisika|Universitas Andalas, 11(1), 9-15. https://doi.org/10.25077/jif.11.1.812.2019.

Sirait, S. G., \& Sugito, Y. (2020). Respon Dua Tipe Tanaman Buncis (Phaseolus vulgaris L.) Terhadap Berbagai Dosis Pupuk Kandang Kambing. Jurnal Produksi Tanaman, 8(8), Article 8. https://doi.org/10.21176/protan.v8i8.1 447.

Srirejeki, D. I., Maghfoer, M. D., \& Herlina, N. (2015). Aplikasi Pgpr Dan Dekamon Serta Pemangkasan Pucuk Untuk Meningkatkan Produktivitas Tanaman Buncis (Phaseolus Vulgaris L.) Tipe Tegak. Jurnal Produksi Tanaman, 3(4), Article https://doi.org/10.21176/protan.v3i4.204.

Syaifuddin, M. A. (2011). Perbedaan Derajat Insomnia Pada Penduduk Yang Terpapar Radiasi Gelombang Elektromagnetik Di Sekitar Saluran Udara Tegangan Ekstra Tinggi 